\title{
The Process of Inquiry-Based Teaching Practices from the Perspective of Prospective Mathematics Teachers
}

\author{
Rabia Sarıca - Bayram Çetin* \\ Received: January 22, 2020; received in revised form: April 14, 2020; \\ accepted: April 15, 2020
}

\begin{abstract}
:
Introduction: Inquiry-based teaching is a constructivist-based method that has become popular in recent years. In this method, students work in a systematic way like a scientist during the research process, actively participate in the learning process, solve problems and learn in practice. The aim of this study is to reveal the opinions of prospective teachers about inquiry based teaching practices.

Methods: The study was designed in a qualitative research design. The participants of the study are primary mathematics teacher candidates. Data were collected through semi-structured interviews conducted face-to-face with the students. The data were analyzed using content analysis. The findings obtained from the analysis of the prospective teachers' views were presented with the relevant themes and codes under the titles.

Results: Some of the findings of the prospective teachers' opinions about the process in which inquiry-based teaching method is applied are as follows. It provides permanent learning, is suitable for real life, develops skills such as research, problem solving, leadership, motivates and gives experience to the profession, is learned actively by doing and experiencing in the process, unexpected difficulties are encountered, the traditional method is easier, not suitable for every course, the lecturer should give more feedback and guidance, communication and coordination in group work is required.

Discussion: Prospective teachers stated many positive opinions about the process in which the course content was taught using inquiry-based method. It can be said that the application process positively influences the practical knowledge and skills of teacher candidates. However, it is seen that some prospective teachers find the process tiring and time consuming. It is understood that teacher candidates have intense concerns about Public Personnel Selection Examination (KPSS) and this affects the process.
\end{abstract}

\footnotetext{
* Rabia Sarıca, Ahi Evran University, Kirşehir, Turkey; rabiasarica@gmail.com Bayram Çetin, Gazi University, Ankara, Turkey; bcetin27@gmail.com
} 


\title{
Acta Educationis Generalis \\ Volume 10, 2020, Issue 3
}

\begin{abstract}
KPSS is a test in Turkey for prospective teachers where they should get enough points to be appointed as teachers after graduation. Although the participants of this study are 3rd grade prospective teachers and they take the KPSS exam after graduation; it is understood that KPSS affects them and their motivation.
\end{abstract}

Limitations: This research is limited to the measurement and evaluation course and to the 3 rd grade mathematics teacher candidates who are the participants of this study.

Conclusions: Prospective teachers mostly have positive opinions about the inquiry-based teaching process. It can be said that it would be beneficial to use this method in teacher education.

Key words: inquiry-based teaching, prospective teachers, teacher education.

\section{Introduction}

One of the most prominent learning-teaching approaches along with the changes in the understanding of education is inquiry-based learning-teaching. Inquirybased learning is a student-centered approach that has been emphasized in recent years, which draws attention to the acquisition of extremely important skills for today's world, such as research-inquiry, learning to learn and problem solving. It is stated that the foundations of inquiry-based learning that focuses on high-level thinking skills rather than learning of knowledge are based on Socrates' questioning approach, Dewey's problem-solving method and constructivism philosophy (Bostan-Sarığlan et al., 2016). According to Feletti (1993), inquirybased learning is an approach that offers students the opportunity to customize their knowledge through exploration, research and observation, that is, to create meaning individually (as cited in Chang et al., 2016).

Students are not passive recipients of content in inquiry-based learning environments. On the contrary, they actively participate in the process and achieve their own learning, in particular by linking new information with their previous knowledge. The students who are responsible for their own learning reach the sources of information by researching, associate the new information with the previous ones, and create new information by using research and reasoning in this process (Alkan-Dilbaz, Yanpar-Yelken, \& Özgelen, 2013). In this approach, which is based on open-ended, student-centered, hands-on learning through hands-on activities, students actively participate in the teaching-learning process in contrast to teacher-centered classes (Chang et al., 2016). Concerning inquiry-based learning, Heindl (2019) reports that Messner (2009) considers this type of learning as a preliminary stage for project-based, research/exploration and problem-based scientific studies and Reitinger (2013) explains the basic components of this definition of learning as cognitive interest, discovery, hypothesis formation, methodology determination, negotiation- 


\section{Acta Educationis Generalis \\ Volume 10, 2020, Issue 3}

discourse and publication of results. According to Tatar and Kuru (2006), in the inquiry-based learning process, students work like scientists and use scientific research methods. Students plan, practice and evaluate their own research processes. At the same time, they learn the subject content practically, which means they learn by doing and experiencing. Students sometimes study individually and sometimes study in groups.

According to Akınoğlu (2004), in inquiry-based teaching (IBT), which is one of the teaching practices of the constructivist paradigm, after the problematic situation is presented to the students by the teacher, the students formulate hypotheses and collect the necessary information by selecting the appropriate methods, they work on the data they collected and make comments, and they present and discuss the result in the classroom, or in other appropriate settings. Therefore, the first stage of this learning approach is exploring, the second stage is sharing and discussing the content, and the third stage is the practice and development. It is stated that inquiry-based learning can be applied in various ways, but is often characterized by practical scenarios, and these scenarios direct students to deep learning on the subject, and that students study in small groups to determine learning areas and research topics and give feedback to each other and in this way, they gain extensive information about many practical ideas (Stacey et al., 2018). It is expressed that in the inquiry-based learning process, students actively solve problems, make discussions, access information by themselves and inquire about the information they access and it is stated that their skills to take responsibility, study in a group and treat their friends with respect will be developed and their self-confidence will be increased in these ways (Duran \& Dökme, 2018). It is specified that inquiry-based teaching, which is an effective teaching strategy, can be in the form of a problem or task to enable and increase the participation of students. However, it is emphasized that it is still unclear how students will be involved in purposeful research activities; these kinds of problems should be solved especially for social sciences courses (Hwang et al., 2015).

There is a growing interest in this approach in Turkey, as well as abroad. This interest is observed both in the increase in the academic studies related to the subject and in the curriculum studies carried out by the Ministry of National Education (MNE). In the updated science curriculum, students are expected to be raised as individuals who are responsible for their own learning by forming their learning through discovery and questioning processes, who can actively obtain information by researching-questioning and doing-experiencing, who can question and transform the obtained information into a product, who can cooperate and who have advanced communication skills (MNE, 2018). It is also stated in the same educational program that an inquiry-based learning approach is selected as a baseline for science course as an interdisciplinary perspective. It is observed that STEM, which is an interdisciplinary approach, comes to the forefront in the program. It is seen that the studies related to inquiry-based 


\section{Acta Educationis Generalis \\ Volume 10, 2020, Issue 3}

teaching are concentrated especially on science classes and mostly in primary and secondary school levels. Applying this method not only in certain disciplines such as science courses, but also in different disciplines such as social sciences, medicine, law and at different levels is considered important. Therefore, in this study, the undergraduate level was chosen as the level; measurement and evaluation, which is one of the professional teaching knowledge courses, was chosen as the course. Also, the prospective teachers were selected as participants. It is reported that the number of studies showing the benefits of inquiry-based learning is increasing, but technically, it is ineffective due to teachers' traditional beliefs, perceptions and inadequacies in practice (Duran \& Dökme, 2018). Considering all these together, prospective teachers are required to train their students with the competence to research and produce knowledge, since they will teach in the information age. Theoretical information about these approaches is given to prospective teachers frequently and intensively. However, in order to be able to apply these approaches and methods in the classroom, they must first have sufficient experience in this field. The aim of this study is to reveal the opinions of prospective mathematics teachers about the inquiry-based teaching practices after experiencing the measurement and evaluation course, one of the undergraduate courses as inquiry-based teaching practices.

\section{Methods}

In this study, it is aimed to investigate the opinions of prospective mathematics teachers about inquiry-based teaching practices. This study covers the qualitative part of the thesis in which both qualitative and quantitative approaches used. In the thesis study, an inquiry-based teaching-oriented course was conducted and the opinions of prospective teachers (PT) about this process were revealed and examined. The course, which is focused on inquiry-based teaching method, is a measurement and evaluation course in the undergraduate programs of teaching. Measurement and evaluation course (ME) was conducted during the semester in the form of inquiry-based teaching activities and the opinions of prospective teachers about this process were investigated. Qualitative research approach was adopted in the study. The qualitative research approach is used to discover and learn the meaning that individuals or groups attribute to a social issue or phenomenon (Creswell, 2013). The most typical feature of qualitative research is that the subject is discussed from the point of view of the participants (Ekiz, 2009).

\subsection{Participants}

The participants of the study consisted of 3rd grade junior mathematics teaching students studying at Gaziantep University in Turkey. The experimental group of the study consists of 30 prospective mathematics teachers. Twenty-four of the 


\section{Acta Educationis Generalis \\ Volume 10, 2020, Issue 3}

participants were female, six of the participants were male, and the mean age of them is 21.30 . Table 1 shows detailed information regarding the study group.

Table 1

\begin{tabular}{|c|c|c|c|}
\hline Quality & Level & $f$ & $\underline{\%}$ \\
\hline \multirow{4}{*}{ General Academic Average } & 3.01 to 4.00 & 4 & 13.3 \\
\hline & 2.01 to 3.00 & 25 & 83.4 \\
\hline & 1.00 to 2.00 & 1 & 3.3 \\
\hline & Between 2000 Turkish Lira (TL)- 500 TL & 10 & 33.3 \\
\hline \multirow{3}{*}{$\begin{array}{l}\text { Average Monthly Income of the } \\
\text { Family }\end{array}$} & Between 3500 TL- 2001 TL & 13 & 43.4 \\
\hline & Between 5000 TL- $3501 \mathrm{TL}$ & 5 & 20.0 \\
\hline & $50001 \mathrm{TL}$ and more & 2 & 6.7 \\
\hline \multirow{2}{*}{ Personal Computer } & Available & 23 & 76.7 \\
\hline & Not available & 7 & 23.3 \\
\hline \multirow{3}{*}{$\begin{array}{l}\text { Quick and Accurate Search on } \\
\text { the Internet }\end{array}$} & Yes & 28 & 93.3 \\
\hline & No & 2 & 6.7 \\
\hline & Illiterate & 1 & 3.3 \\
\hline \multirow{5}{*}{ Mother's Educational Status } & Primary school graduate & 13 & 43.3 \\
\hline & Secondary school graduate & 4 & 13.3 \\
\hline & High school graduate & 8 & 26.7 \\
\hline & University/College graduate & 4 & 13.3 \\
\hline & Illiterate & - & - \\
\hline \multirow{4}{*}{ Father's Educational Status } & Primary school graduate & 5 & 16.7 \\
\hline & Secondary school graduate & 7 & 23.3 \\
\hline & High school graduate & 9 & 30.0 \\
\hline & University/College graduate & 9 & 30.0 \\
\hline \multirow{5}{*}{ Shelter } & Dorm & 5 & 16.6 \\
\hline & With a relative & 1 & 3.3 \\
\hline & At home with friends & 7 & 26.7 \\
\hline & With family & 11 & 36.7 \\
\hline & Apart house & 5 & 16.7 \\
\hline \multirow{4}{*}{$\begin{array}{l}\text { Resources Used to Access } \\
\text { Information }\end{array}$} & Internet & 26 & 57.8 \\
\hline & Library & 5 & 11.1 \\
\hline & Books, magazines etc. available at home. & 8 & 17.8 \\
\hline & Experts & 6 & 13.3 \\
\hline
\end{tabular}

\subsection{Data analysis}

Afterwards, the data were analyzed by content analysis. In the content analysis process, the data are examined systematically and thematically in the context of categories (Saban, 2009). Within the scope of this study, the data were analyzed by the researcher and the expert. The expert, who has worked in this process, is an academician who is an expert in the fields such as statistics, assessment- 


\section{Acta Educationis Generalis \\ Volume 10, 2020, Issue 3}

evaluation, qualitative and quantitative data analysis and has many studies in these fields. In the process of qualitative data analysis, firstly, the researcher and the expert worked independently and designated the themes. They then came together to discuss themes, such as the names of the themes, codes, criteria, and they worked until they adopt a common decision. After a common decision was taken on the theme names, the similar process was repeated, and the scope of the theme and the sample sentences were created in such a way that there was no difference of opinion. Afterwards, they decided to collect the similar themes under the same title by considering the scope of the agreed themes. In this context, the following titles were established for all data analyzed. These titles are as follows:

1. the benefits of inquiry-based teaching for the measurement and evaluation course;

2. the benefits of inquiry-based teaching to gain skills;

3. the benefits of inquiry-based teaching to getting ready for the profession;

4. characteristics of inquiry-based teaching process regarding individuals;

5. characteristics of the nature of the inquiry-based teaching process;

6. characteristics of the inquiry-based teaching process regarding the instructor;

7. factors affecting inquiry-based teaching;

8. negative aspects of inquiry-based teaching.

Information on the agreed themes, codes, and criteria regarding these are given in Table 2.

Table 2

\begin{tabular}{|c|c|c|c|}
\hline Title & Theme & Codes & Criteria \\
\hline \multirow{3}{*}{$\begin{array}{l}\text { The benefits of } \\
\text { inquiry-based } \\
\text { teaching for the } \\
\text { measurement } \\
\text { and evaluation } \\
\text { course }\end{array}$} & $\begin{array}{l}\text { The process carried } \\
\text { out with IBT } \\
\text { activities ensures } \\
\text { permanent learning. }\end{array}$ & Permanency & $\begin{array}{l}\text { Statements related to } \\
\text { permanent learning are } \\
\text { evaluated in this } \\
\text { context. }\end{array}$ \\
\hline & $\begin{array}{l}\text { Using IBT in the ME } \\
\text { course provides an } \\
\text { opportunity to see } \\
\text { how information is } \\
\text { applied in real life. }\end{array}$ & $\begin{array}{l}\text { Appropriate to } \\
\text { real life }\end{array}$ & $\begin{array}{l}\text { Sentences regarding } \\
\text { the appropriateness of } \\
\text { knowledge and } \\
\text { teaching to real life are } \\
\text { evaluated within this } \\
\text { scope. }\end{array}$ \\
\hline & $\begin{array}{l}\text { The use of the IBT } \\
\text { process in the ME } \\
\text { course raises } \\
\text { awareness of the } \\
\text { importance of test } \\
\text { development, exam } \\
\text { preparation, question }\end{array}$ & Awareness & $\begin{array}{l}\text { Emphasizing the } \\
\text { importance of the } \\
\text { subjects of the ME } \\
\text { course and sentences } \\
\text { indicating that this is } \\
\text { understood are } \\
\text { evaluated in this }\end{array}$ \\
\hline
\end{tabular}




\section{Acta Educationis Generalis \\ Volume 10, 2020, Issue 3}

writing, and item

analysis.

\section{IBT develops}

research skills and enables them to be used in daily life.

In IBT, group study develops students in terms of developing friendship, selfexpression, and peer learning.

IBT allows students to socialize.

Socialization

The IBT process

The benefits of inquiry-based teaching to gain skills

improves problemsolving skills.

Group study improves the students
Problem-Solving

Research skills Statements related to research skills are evaluated in this context.

The expressions for the benefit of group study are included in this scope.

Expressions such as stating that sociality is gained in the process where this method is used are evaluated within this scope.

Conditions such as problem solving, revealing the problem, determining the problem are examined in this context.

Making interpretations

The IBT process

improves

interpretation skills.

Group study

conducted in IBT

improves leadership

characteristics and

self-confidence.

Students who are interested in different and extraordinary practices are not concerned about inquiry-based learning. The IBT process improves individual
Interpretation

Leadership and self-confidence

and inferences are evaluated in this context.

Leadership and related statements in group studies and sentences stating that it reinforces selfconfidence are evaluated within this scope.

Sentences indicating that the activities are extraordinary and

Extraordinariness interesting are examined in this context.

The statements regarding the decision- 


\begin{tabular}{|c|c|c|c|}
\hline & $\begin{array}{l}\text { and collective } \\
\text { decision-making } \\
\text { skills. }\end{array}$ & & $\begin{array}{l}\text { making process and } \\
\text { decision-making skills } \\
\text { are evaluated within } \\
\text { this scope. }\end{array}$ \\
\hline \multirow{3}{*}{$\begin{array}{l}\text { The benefits of } \\
\text { inquiry-based } \\
\text { teaching to } \\
\text { getting ready for } \\
\text { the profession }\end{array}$} & $\begin{array}{l}\text { Using IBT in the ME } \\
\text { course gives the } \\
\text { opportunity to get to } \\
\text { know the real school } \\
\text { environment. This is } \\
\text { a good experience for } \\
\text { prospective teachers } \\
\text { before they start } \\
\text { serving. }\end{array}$ & $\begin{array}{l}\text { Gaining } \\
\text { experience }\end{array}$ & $\begin{array}{l}\text { Expressions that } \\
\text { processing ME with } \\
\text { IBT activities gives PT } \\
\text { the opportunity to get } \\
\text { to know the schools } \\
\text { and that it is a good } \\
\text { experience for PT } \\
\text { before the service are } \\
\text { evaluated in this } \\
\text { context. }\end{array}$ \\
\hline & $\begin{array}{l}\text { The use of the IBT } \\
\text { process in the ME } \\
\text { course motivates } \\
\text { teacher candidates to } \\
\text { the profession. }\end{array}$ & $\begin{array}{l}\text { Professional } \\
\text { motivation }\end{array}$ & $\begin{array}{l}\text { The statements } \\
\text { suggesting that } \\
\text { teaching the ME } \\
\text { course with IBT } \\
\text { practices increases } \\
\text { motivation for the } \\
\text { teaching profession. }\end{array}$ \\
\hline & $\begin{array}{l}\text { The use of IBT in the } \\
\text { ME course gives the } \\
\text { prospective teacher } \\
\text { the opportunity to } \\
\text { identify students' } \\
\text { misconceptions. }\end{array}$ & Misconception & $\begin{array}{l}\text { It includes the } \\
\text { situations that the PT } \\
\text { realizes the } \\
\text { misconception of the } \\
\text { students according to } \\
\text { the activities carried } \\
\text { out. }\end{array}$ \\
\hline \multirow{3}{*}{$\begin{array}{l}\text { Characteristics } \\
\text { of inquiry-based } \\
\text { teaching process } \\
\text { regarding } \\
\text { individuals }\end{array}$} & $\begin{array}{l}\text { In the inquiry-based } \\
\text { method, the student } \\
\text { undertakes the } \\
\text { responsibility of } \\
\text { learning. }\end{array}$ & Responsibility & $\begin{array}{l}\text { PT's statements that } \\
\text { the responsibility for } \\
\text { learning during the } \\
\text { process belongs to the } \\
\text { students are included } \\
\text { in this scope. }\end{array}$ \\
\hline & $\begin{array}{l}\text { The student must be } \\
\text { active in the IBT } \\
\text { process. }\end{array}$ & Active students & $\begin{array}{l}\text { It includes the } \\
\text { statements of the PT } \\
\text { about students being } \\
\text { active during the } \\
\text { process. }\end{array}$ \\
\hline & $\begin{array}{l}\text { In the IBT process, } \\
\text { the individual should } \\
\text { obtain the } \\
\text { information from } \\
\text { different sources and }\end{array}$ & $\begin{array}{l}\text { Obtaining } \\
\text { information }\end{array}$ & $\begin{array}{l}\text { The statements } \\
\text { reflecting the opinions } \\
\text { on gaining information } \\
\text { in the IBT process are } \\
\text { included in this scope. }\end{array}$ \\
\hline
\end{tabular}




\section{Acta Educationis Generalis \\ Volume 10, 2020, Issue 3}

\begin{tabular}{|c|c|c|c|}
\hline & $\begin{array}{l}\text { During the IBT } \\
\text { process, the student } \\
\text { also studies outside } \\
\text { the class hours. }\end{array}$ & $\begin{array}{l}\text { Out-of-class } \\
\text { activity }\end{array}$ & $\begin{array}{l}\text { It covers the } \\
\text { statements regarding } \\
\text { performing } \\
\text { extracurricular } \\
\text { activities. }\end{array}$ \\
\hline & $\begin{array}{l}\text { In IBT, the student } \\
\text { should use time well. }\end{array}$ & Time & $\begin{array}{l}\text { It covers the use of } \\
\text { time effectively by the } \\
\text { PT when performing } \\
\text { activities in the } \\
\text { process. }\end{array}$ \\
\hline & $\begin{array}{l}\text { In the IBT process, } \\
\text { the student can make } \\
\text { mistakes until she/he } \\
\text { reaches the correct } \\
\text { information. }\end{array}$ & Making mistake & $\begin{array}{l}\text { It includes statements } \\
\text { about making mistakes } \\
\text { until obtaining the } \\
\text { reliable information } \\
\text { and correcting the } \\
\text { mistakes in the } \\
\text { process. }\end{array}$ \\
\hline & $\begin{array}{l}\text { In IBT, the } \\
\text { individual enters into } \\
\text { an intensive process } \\
\text { of asking questions. }\end{array}$ & Asking question & $\begin{array}{l}\text { It includes statements } \\
\text { that the process begins } \\
\text { and continues with } \\
\text { asking questions. }\end{array}$ \\
\hline \multirow{5}{*}{$\begin{array}{l}\text { Characteristics } \\
\text { of the nature of } \\
\text { the inquiry- } \\
\text { based teaching } \\
\text { process }\end{array}$} & $\begin{array}{l}\text { In inquiry-based } \\
\text { teaching, students } \\
\text { learn by doing and } \\
\text { experiencing. }\end{array}$ & $\begin{array}{l}\text { Learning by } \\
\text { doing- by } \\
\text { experiencing }\end{array}$ & $\begin{array}{l}\text { Expressions related to } \\
\text { learning by doing and } \\
\text { experiencing in the } \\
\text { process. }\end{array}$ \\
\hline & $\begin{array}{l}\text { Unexpected } \\
\text { challenges may occur } \\
\text { during the IBT } \\
\text { process. }\end{array}$ & $\begin{array}{l}\text { Unexpected } \\
\text { challenges }\end{array}$ & $\begin{array}{l}\text { It covers unexpected } \\
\text { difficulties and } \\
\text { problems in the } \\
\text { process. }\end{array}$ \\
\hline & $\begin{array}{l}\text { Traditional teaching } \\
\text { is easier than inquiry- } \\
\text { based teaching. }\end{array}$ & Traditional-easy & $\begin{array}{l}\text { Sentences suggesting } \\
\text { that the traditional } \\
\text { approach is easier. }\end{array}$ \\
\hline & $\begin{array}{l}\text { The IBT method is } \\
\text { not applicable for } \\
\text { every course. }\end{array}$ & $\begin{array}{l}\text { Not applicable for } \\
\text { every course }\end{array}$ & $\begin{array}{l}\text { These are the opinions } \\
\text { stating that this method } \\
\text { is not applicable for } \\
\text { every course. }\end{array}$ \\
\hline & $\begin{array}{l}\text { The use of IBT } \\
\text { activities in the ME } \\
\text { course is not } \\
\text { intended to prepare } \\
\text { the prospective } \\
\text { teachers for the }\end{array}$ & KPSS & $\begin{array}{l}\text { It covers the opinions } \\
\text { such as the ME course } \\
\text { carried out by this } \\
\text { method does not } \\
\text { prepare the prospective } \\
\text { teachers for the KPSS. }\end{array}$ \\
\hline
\end{tabular}




\section{Acta Educationis Generalis \\ Volume 10, 2020, Issue 3}

Personnel Selection

Examination).

In inquiry-based

teaching, students

learn by doing and

experiencing.
Compliance with

the course
It covers the

statements such as this method may be

particularly

appropriate for ME

and other educational

science courses, but

may not be applicable

for some

field/Mathematic

courses.

It covers the opinions

Students should be

given more guidance

and feedback for

IBT.

of the inquiry-

based teaching process

regarding the

instructor

In IBT, sufficient

time should be provided to students to complete their research.

Good communication

and coordination

among group

members is required

in group study in

inquiry-based

teaching process.

The negative attitude

Factors affecting

inquiry-based

teaching towards research also

affects the process

negatively.

The fact that students are not accustomed to the process of the method negatively affects the IBT process.

Exam (score)

concern affects the attitude towards ME course conducted
Guidance and

feedback
Negative attitude and bias

Being not accustomed to the process

Exam(score) concern about expecting more

help, feedback, and guidance from the instructor.

It includes the opinions such as sufficient time should be provided to carry out the activities.

Communication, coordination, and efficiency

It covers the opinions such as communication and coordination are important in group studies and they affect the efficiency of the study.

It includes the opinions such as negative attitudes, thoughts and judgments towards the research affect the process negatively.

It includes the statements of the PT that students are not accustomed to this method.

It includes the opinions such as exam (score) concerns affect the attitude towards the 


\section{Acta Educationis Generalis \\ Volume 10, 2020, Issue 3}

\begin{tabular}{|c|c|c|c|}
\hline & $\begin{array}{l}\text { with IBT activities. } \\
\text { The use of IBT } \\
\text { activities in the ME } \\
\text { course negatively } \\
\text { affects the } \\
\text { motivation for the } \\
\text { course, as it is not } \\
\text { oriented for KPSS } \\
\text { and school exams. }\end{array}$ & KPSS motivation & $\begin{array}{l}\text { course. } \\
\text { Since the practices are } \\
\text { not intended to prepare } \\
\text { the candidates for the } \\
\text { KPSS, the motivation } \\
\text { of the prospective } \\
\text { teachers is affected. }\end{array}$ \\
\hline \multirow{6}{*}{$\begin{array}{l}\text { Negative aspects } \\
\text { of inquiry-based } \\
\text { teaching }\end{array}$} & $\begin{array}{l}\text { IBT is a challenging } \\
\text { process. }\end{array}$ & Challenging & $\begin{array}{l}\text { It includes the ideas } \\
\text { that the process is } \\
\text { challenging. }\end{array}$ \\
\hline & $\begin{array}{l}\text { The IBT process may } \\
\text { not increase interest } \\
\text { towards the ME } \\
\text { course. }\end{array}$ & Interest & \multirow{2}{*}{$\begin{array}{l}\text { It covers the ideas that } \\
\text { the method will not } \\
\text { increase the interest } \\
\text { towards the course. } \\
\text { It includes the ideas } \\
\text { that the process is a } \\
\text { time-consuming and } \\
\text { sometimes tiring. }\end{array}$} \\
\hline & $\begin{array}{l}\text { The IBT process is a } \\
\text { time-consuming and } \\
\text { sometimes tiring } \\
\text { process. }\end{array}$ & $\begin{array}{l}\text { Time-consuming } \\
\text { and tiring }\end{array}$ & \\
\hline & $\begin{array}{l}\text { The idea that } \\
\text { students are not } \\
\text { accustomed to this } \\
\text { method and that they } \\
\text { are responsible for } \\
\text { their own learning } \\
\text { can create anxiety in } \\
\text { the process. }\end{array}$ & Anxiety & $\begin{array}{l}\text { It includes the opinions } \\
\text { of PT such as being } \\
\text { not accustomed to this } \\
\text { method and } \\
\text { undertaking the } \\
\text { responsibility of } \\
\text { learning can } \\
\text { sometimes cause } \\
\text { anxiety in the process. }\end{array}$ \\
\hline & $\begin{array}{l}\text { Excessive workload } \\
\text { in the IBT process } \\
\text { negatively affects } \\
\text { students' motivation. }\end{array}$ & $\begin{array}{l}\text { Excessive } \\
\text { workload }\end{array}$ & $\begin{array}{l}\text { It covers the PT's } \\
\text { views on the increase } \\
\text { of workloads in the } \\
\text { process. }\end{array}$ \\
\hline & $\begin{array}{l}\text { The use of IBT in the } \\
\text { ME course suggests } \\
\text { that it is difficult to } \\
\text { prepare alternative } \\
\text { ME instruments. }\end{array}$ & $\begin{array}{l}\text { Difficult } \\
\text { alternative }\end{array}$ & $\begin{array}{l}\text { The views regarding } \\
\text { the fact that preparing } \\
\text { alternative ME } \\
\text { instruments is difficult } \\
\text { is evaluated within this } \\
\text { framework. }\end{array}$ \\
\hline
\end{tabular}

The researcher and the expert independently analyzed the data in the context of the themes agreed upon. The intercoder reliability was calculated separately for each title and it was calculated by using the formula of Reliability $=$ [Consensus/ (Consensus+ Disagreement)] * 100 proposed by Miles \& Huberman (1994). The intercoder reliability values obtained for each title are given in Table 3. 


\section{Acta Educationis Generalis \\ Volume 10, 2020, Issue 3}

Table 3

The intercoder reliability values

\begin{tabular}{|c|c|c|c|c|}
\hline$\underline{N o}$ & $\underline{\text { Title }}$ & $\frac{\text { Number of }}{\frac{\text { themes }}{\text { agreed }}}$ & $\frac{\frac{\text { Number of }}{\text { disagreed }}}{\underline{\text { themes }}}$ & $\frac{\text { Reliability }}{\underline{\text { value }}}$ \\
\hline 1 & $\begin{array}{l}\text { The benefits of inquiry-based } \\
\text { teaching for the measurement and } \\
\text { evaluation course }\end{array}$ & 99 & 14 & 0.89 \\
\hline 2 & $\begin{array}{l}\text { The benefits of inquiry-based } \\
\text { teaching to gain skills }\end{array}$ & 146 & 16 & 0.90 \\
\hline 3 & $\begin{array}{l}\text { The benefits of inquiry-based } \\
\text { teaching to getting ready for the } \\
\text { profession }\end{array}$ & 76 & 11 & 0.87 \\
\hline 4 & $\begin{array}{l}\text { Characteristics of inquiry-based } \\
\text { teaching process regarding } \\
\text { individuals }\end{array}$ & 180 & 31 & 0.85 \\
\hline 5 & $\begin{array}{l}\text { Characteristics of the nature of the } \\
\text { inquiry-based teaching process }\end{array}$ & 125 & 19 & 0.87 \\
\hline 6 & $\begin{array}{l}\text { Characteristics of the inquiry-based } \\
\text { teaching process regarding the } \\
\text { instructor }\end{array}$ & 35 & 6 & 0.85 \\
\hline 7 & $\begin{array}{l}\text { Factors affecting inquiry-based } \\
\text { teaching }\end{array}$ & 91 & 18 & 0.83 \\
\hline \multirow[t]{2}{*}{8} & $\begin{array}{l}\text { Negative aspects of inquiry-based } \\
\text { teaching }\end{array}$ & 79 & 11 & 0.88 \\
\hline & $\begin{array}{l}\text { All themes covering all qualitative } \\
\text { data }\end{array}$ & 831 & 126 & 0.87 \\
\hline
\end{tabular}

\section{Findings}

As a result of qualitative analysis of the prospective teachers' opinions about inquiry-based teaching, eight sub-topics are found. In this section, the findings related to each topic are presented separately. In addition, the frequency values of some codes in the analysis presented in this section are higher than the number of participants. At this point, the strategy of incorporating the same codes, which are repeated in different places in the opinions of the participants, into the frequency value was adopted with the common opinion of the expert, researcher and thesis supervisor involved in the data analysis and this approach was used in the analysis of the data.

\subsection{The benefits of inquiry-based teaching for the measurement and evaluation course}

The views of prospective teachers on the benefits of IBT to the ME course were examined under the codes of "permanency", "appropriate to real life" and 


\section{Acta Educationis Generalis \\ Volume 10, 2020, Issue 3}

"raising awareness." Codes, frequency values for codes and sample participant opinions are given in Table 4.

\section{Table 4}

Benefits of IBT for the ME course

\begin{tabular}{|c|c|c|c|}
\hline Theme & Codes & $f$ & Participant Opinion Sample \\
\hline $\begin{array}{l}\text { The process carried out by IBT } \\
\text { activities ensures permanent } \\
\text { learning. }\end{array}$ & Permanency & 50 & $\begin{array}{l}\text { It was more permanent because } \\
\text { we did it in our own... (PT12) }\end{array}$ \\
\hline $\begin{array}{l}\text { Using IBT in the ME course } \\
\text { provides an opportunity to see } \\
\text { how information is applied in } \\
\text { real life. }\end{array}$ & $\begin{array}{l}\text { Appropriate } \\
\text { to real life }\end{array}$ & 35 & $\begin{array}{l}\ldots \text { It was more appropriate to } \\
\text { the real life but I don't what to } \\
\text { do with KPSS now... (PT11) }\end{array}$ \\
\hline $\begin{array}{l}\text { The use of the IBT process in } \\
\text { the ME course raises awareness } \\
\text { of the importance of test } \\
\text { development, exam preparation, } \\
\text { question writing, and item } \\
\text { analysis. }\end{array}$ & Awareness & 28 & $\begin{array}{l}\text { In particular, test development, } \\
\text { question preparation and } \\
\text { question types were very } \\
\text { helpful. Because we will } \\
\text { prepare questions in the } \\
\text { future... (PT6) }\end{array}$ \\
\hline
\end{tabular}

As seen in Table 4, permanency code, appropriateness to real life code and awareness code were repeated 50, 35 and 28 times, respectively in qualitative data.

\subsection{The benefits of inquiry-based teaching to gain skills}

Prospective teachers' opinions about the benefits of IBT to gain skills were examined under the codes of "research skills", "group study improves the students", "socialization", "problem-solving", "interpretation", "leadership and self-confidence", "extraordinariness", and "decision-making." Codes, frequency values for codes and sample prospective teachers' opinions are given in Table 5.

Table 5

\section{The benefits of IBT to gain skills}

Theme

IBT develops research skills and enables them to be used in daily life.

In IBT, group study develops students in terms of developing friendship, self$\underline{\text { Codes }}$

Research skills expression, and peer
Group study improves the students
Participant Opinion Sample ... Since we questioned many things we didn't know, researched, our research skills improved... (PT4)

30 Of course, studying in groups has made improvements... (PT1) 


\section{Acta Educationis Generalis \\ Volume 10, 2020, Issue 3}

learning.

IBT allows students to socialize.

Socialization

The IBT process improves problemsolving skills.

The IBT process improves interpretation skills.

Group study conducted in IBT improves

leadership

characteristics and selfconfidence.

Students who are interested in different and extraordinary practices are not concerned about inquiry-based learning.

The IBT process improves individual and collective decisionmaking skills.
Frankly, I am not a social person; I

26 developed myself in cooperation...I gained sociability... (PT4)

Problem-Solving

17 ... Sometimes we encountered problems and solved them... (PT8)

... Then, the report formats that you provided were not in a way

Interpretation that take this information and apply

14 it on your paper, you rather demanded from us to make interpretations. I also improved my interpretation skills. (PT4)

... I led the group and I think it

Leadership and self-confidence contributed to me. Its contribution to me is mostly in this direction, which gives me self-confidence... (PT7)

It was important to me that the course was extraordinary, and I Extraordinariness wasn't worried, because, I thought that at least one course should be different. I wasn't concerned about the course... (PT10)

...There were discussions while studying in groups; many different ideas came out and we made decision on them. Everyone gave up their decisions one by one and made a joint decision... (PT12)

As seen in Table 5, the codes of research skills, group study improves the students, socialization, problem-solving, interpretation, leadership and selfconfidence, extraordinariness and decision-making were repeated 45, 30, 26, 17 , $14,11,8$ and 5 times, respectively in qualitative data.

\subsection{The benefits of inquiry-based teaching to getting ready for the profession}

Prospective teachers' opinions about the benefits of IBT to prepare the prospective teachers to the profession were examined under the codes of "gaining experience", "professional motivation", and "misconception." Codes, frequency values for codes and sample prospective teachers' opinions are given in Table 6. 


\section{Acta Educationis Generalis \\ Volume 10, 2020, Issue 3}

Table 6

The benefits of IBT to prepare the prospective teachers to the profession

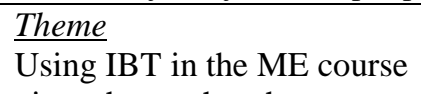

gives the teacher the opportunity to get to know the school environment. This is a good experience for

Gaining
experience Codes prospective teachers before they start serving.

The use of the IBT process in the ME course motivates the teacher to the profession.
Professional motivation $f \quad$ Participant Opinion Sample ... It contributed me, other 49 than that, it was useful for us to gain experience by going to the schools. (PT9)

Every time we went there, they asked questions like "Are you an intern?" We replied the 34 question as "No." but we wanted to say yes. Now, I really want to be a teacher. (PT1)

The use of IBT in the ME course gives the prospective teacher the opportunity to identify students' Misconception $4 \quad \begin{aligned} & \text { In addition, children's } \\ & \text { misconceptions are revealed, }\end{aligned}$ and we noticed it... (PT1) misconceptions.

As seen in Table 6, the codes of gaining experience, professional motivation and misconception were repeated 49,34 and 4 times, respectively in qualitative data.

\subsection{Characteristics of inquiry-based teaching process regarding individuals}

Prospective teachers' opinions about characteristics of IBT process regarding individuals were examined under the codes of "responsibility", "active students", "obtaining information", "out-of-class activity", "time", "making mistake" and "asking question." Codes, frequency values for codes and sample prospective teachers' opinions are given in Table 7.

Table 7

Characteristics of IBT process regarding individuals

\begin{tabular}{llll}
\hline $\begin{array}{l}\text { Theme } \\
\begin{array}{l}\text { In the inquiry-based method, } \\
\text { the student undertakes the } \\
\text { responsibility of learning. }\end{array}\end{array}$ & $\begin{array}{l}\text { Codes } \\
\text { Responsibility }\end{array}$ & $\begin{array}{l}\text { Participant Opinion Sample } \\
\text {.. In this way, we learned by } \\
\text { investigating and questioning. I } \\
\text { think that it could be better. } \\
\text { (PT1) }\end{array}$ \\
$\begin{array}{l}\text { The student must be active in } \\
\text { the IBT process. }\end{array}$ & $\begin{array}{l}\text { Active } \\
\text { students }\end{array}$ & 40 & $\begin{array}{l}\text {..The course became more } \\
\text { effective with this method; we } \\
\text { obtained a little more dynamic }\end{array}$
\end{tabular}




\section{Acta Educationis Generalis \\ Volume 10, 2020, Issue 3}

In the IBT process, the individual should obtain the information from different sources and effectively.

During the IBT process, the student also studies outside the class hours.

In IBT, the student should use time well.

In the IBT process, the student can make mistakes until she/he reaches the correct information.

In IBT, the individual enters into an intensive process of asking questions.

and active participation. (PT7) ... We learned, but as I said, learning phase was so challenging that we searched on

Obtaining information

Out-of-class activity

Time

Making mistake

Asking question
33 we made research and sometimes all these efforts were not enough. We consulted the teacher, sometimes we got stuck on the subjects...(PT2)

... We can also come together outside the classroom and do 33 activities by gathering the class; we should carry out collective activities. (PT7)

I think the time given was enough, but we are all students (laughs). As you know, we

20 postpone our responsibilities to the last minute; that's why it was a little bit challenging for us... (PT1)

... After all, we learn better when we prepare it on our own. We made it correctly or we made mistakes and we corrected it by consulting to the professionals. (PT2)

... We do not know the subject comprehensively and we need to learn by making research and asking questions. ...(PT3)

As seen in Table 7 , the codes of responsibility, active students, obtaining information, out-of-class activity, time, making mistake and asking question were repeated 56, 40, 33, 20, 15 and 14 times, respectively in qualitative data.

\subsection{Characteristics of the nature of the inquiry-based teaching process}

Prospective teachers' opinions about characteristics of the nature of the IBT process were examined under the codes of "learning by doing-by experiencing", "unexpected challenges", "traditional-easy", "not applicable for every course", "KPSS", "compliance with the course." Codes, frequency values for codes and sample prospective teachers' opinions are given in Table 8. 


\section{Acta Educationis Generalis \\ Volume 10, 2020, Issue 3}

Table 8

Characteristics of the nature of the IBT process

$\underline{\text { Theme }} \quad \underline{\text { Codes }} f$

In inquiry-based teaching, Learning by students learn by doing and doing- by experiencing.

experiencing

Participant Opinion Sample

First, we learned by doing;

Bloom's taxonomy, concept map, grid are really applied in

practice... (PT1)

So we went to schools. Some schools didn't allow us to make an

Unexpected challenges may occur during the IBT process.

Unexpected challenges

39 strange questions like "Why do you have to make an exam? How can we be sure that you are students?" (PT2)

It is still easier for us to listen to

Traditional teaching is easier than inquiry-based teaching.

Traditional-
easy

Not applicable for every course the topics directly from the instructor. We can just sit there and listen to the instructor, even if we will forget afterwards (laughs). (PT1)

It varies depending on the course. It is quite appropriate to the $\mathrm{ME}$

The IBT method is not applicable for every course.

The use of IBT activities in the ME course is not intended to prepare the prospective teachers for the KPSS course, but we are studying at the

12 department of elementary mathematics teaching and applying it to the math courses is very unreasonable. (PT 3)

... So, if we didn't have to take the KPSS, this would be ideal. Since we had to take an exam like

12 KPSS, our aim was to lecture the subject and solve the questions about KPSS and our expectations were not met. (PT7)

I do not want to apply it to all The IBT method is more appropriate to the Educational Sciences Courses.

Compliance with the course courses, but maybe I can apply it in some educational science courses. (PT2)

As seen in Table 8, the codes of learning by doing-by experiencing, unexpected challenges, traditional-easy, not applicable for every course, KPSS, compliance with the course were repeated 42, 39, 20, 12, 12 and 9 times, respectively in the qualitative data. 


\section{Acta Educationis Generalis \\ Volume 10, 2020, Issue 3}

\subsection{Characteristics of the inquiry-based teaching process regarding the instructor}

Prospective teachers' opinions about characteristics of the IBT process regarding the instructor were examined under the codes of "guidance and feedback" and "sufficient time." Codes, frequency values for codes and sample prospective teachers' opinions are given in Table 9.

Table 9

Characteristics of the IBT process regarding the instructor

Theme

More guidance and feedback should be given to students for inquiry-based teaching.

In inquiry-based teaching, students should be given sufficient time to complete their research.

\section{Codes $f \quad$ Participant Opinion Sample}

It is better if the teacher of the course

Guidance and feedback

25 beginning; we can make research afterwards and it can be more effective in this way. (PT1)

Time and duration were enough. I like

Sufficient time 16 the flexible working hours. The group members were already my friends and we didn't have a problem. (PT10)

As seen in Table 9, the codes of guidance and feedback and sufficient time were repeated 25 and 16 times, respectively in qualitative data.

\subsection{Factors affecting inquiry-based teaching}

Prospective teachers' opinions about the factors affecting inquiry-based teaching were examined under the codes of "communication, coordination, and efficiency", "negative attitude and bias", "being not accustomed to the process", "exam (score) concern", and "KPSS motivation." Codes, frequency values for codes and sample prospective teachers' opinions are given in Table 10.

Table 10

Factors affecting inquiry-based teaching

\section{Theme}

Good communication and coordination among group members is required in group study in the inquiry based teaching process.

The negative attitude towards research also

$\underline{\text { Codes }}$

Communication, coordination, and efficiency

Negative attitude and bias $f \quad$ Participant Opinion Sample

... There were friends in the group who did not know how to 32 use them, there was a miscommunication. We couldn't explain it to them; they couldn't manage it. (PT7)

29 The person must be interested and needs to be curious in this 


\section{Acta Educationis Generalis \\ Volume 10, 2020, Issue 3}

affects the process

negatively.

The fact that students are not accustomed to the process negatively affects the IBT process.

Exam (score) concern affects the attitude towards ME course conducted with IBT activities.

The use of IBT activities in the ME course negatively affects the motivation for the course, as it is not oriented for KPSS and school exams.

regard. It is a personal skill. We were not very successful at this point. (PT7)

Being not accustomed to the process

Exam (score) concern

KPSS motivation

13
...We didn't do these things in elementary school, middle

19 school and high school; we are not accustomed to do this...(PT1)

... Our thoughts and feelings could have been more positive if we had not had any exam (score) concerns. (PT7)

...When I studied on the KPSS books, I found out that these were not appropriate to KPSS...(PT6)

As seen in Table 10, the codes of communication, coordination, and efficiency, negative attitude and bias, being not accustomed to the process, exam (score) concern and KPSS motivation were repeated 32, 29, 19, 16 and 13 times, respectively in qualitative data.

\subsection{Negative aspects of inquiry-based teaching}

Prospective teachers' opinions about negative aspects of inquiry-based teaching were examined under the codes of "challenging", "interest", "time-consuming and tiring", "anxiety", "excessive workload", "difficult alternative." Codes, frequency values for codes and sample prospective teachers' opinions are given in Table 11.

\section{Table 11}

Negative aspects of inquiry-based teaching

Theme $\quad \underline{\text { Codes }} \&$ Participant Opinion Sample

...In the usual method, the teacher

IBT is a challenging process.

Challenging

The IBT process may not increase interest towards the ME course.

Interest would tell us, and we would take notes.

24 Then we would study and pass the exam. The other method is difficult because we're not used to it... (PT11)

Frankly, this method did not increase my interest in the course. (PT6) 


\section{Acta Educationis Generalis \\ Volume 10, 2020, Issue 3}

The IBT process is a time-consuming and sometimes tiring process.

The idea that students are not accustomed to this method and that they are responsible for their own learning can create anxiety in the process.

Excessive workload in the IBT process negatively affects students' motivation. The use of IBT in the ME course suggests that it is difficult to prepare alternative ME instruments.
... It is quite difficult to conduct continuous research during a semester,

Timeconsuming and tiring ask, examine, study with the group, share what you have learned with the group, ask questions, answer the questions that you have asked. It is permanent but challenging and timeconsuming at the same time. (PT1)

Anxiety

We felt anxious; I had difficulty in doing it. Information was not provided to us directly, so we conduct studies to get the information. (PT5)

... Because we had to spend time

Excessive workload outside of class; we woke up early to go to school, it definitely increased our workload. (PT9)

... It was quite difficult to prepare

Alternative is Difficult alternative measurement and evaluation instruments, and I don't think I would

use them frequently... (PT5)

As seen in Table 11, the codes of challenging, interest, time-consuming and tiring, anxiety, excessive workload, difficult alternative were repeated 24, 17 , $15,14,13$ and 7 times, respectively in qualitative data.

\section{Discussion}

Prospective teachers' opinions about inquiry-based teaching process were examined under titles, themes and related codes. In this section, the findings related to each theme were examined within the framework of the relevant literature. Accordingly, there are three themes within the scope of the benefits of inquiry-based teaching to the measurement and evaluation course. These include that inquiry-based learning provides permanent learning, and that the use of IBT in the ME course provides an opportunity to observe how the subjects are applied in real life and that the IBT process raises awareness of the importance of the content of the ME course. Similarly, in another study, it is stated that inquiry-based learning is effective in ensuring the permanency of what is learned (Çalışkan \& Turan, 2008). In another study, in which the effect of activities build upon inquiry-based learning was examined, it was specified that this process increased students' knowledge of subject content and learning permanency (Vilardi, 2013). It has been pointed out in different studies that IBT 


\section{Acta Educationis Generalis \\ Volume 10, 2020, Issue 3}

is in line with the real life (Hammer, 1997; Şensoy, 2009). Şensoy (2009) states that IBT is a useful method to prepare prospective teachers for professional life. It is also emphasized that this method provides prospective teachers with professional awareness (Leonhardt, 1998; Madill et al., 2001).

There are eight themes under the title of the benefits of inquiry-based teaching in gaining skills. The first one is that IBT develops research skills and enables them to be used in daily life. Consistent with this finding of the study, it has been reported that inquiry-based learning provides individuals with research skills (Tatar \& Kuru, 2006; Yore, 1984). Another theme is the view that group studies in IBT develop prospective teachers in terms of friendship, self-expression, and peer learning. It is mentioned that group study activities are very important for the social development of the students (Açıkgöz, 2007; Çalışkan, 2008). Another theme includes the prospective teachers' opinion on the fact that IBT helps them to socialize. In this context, one of the prospective teachers expressed her/his opinion as "Frankly, I am not a social person; I developed myself in cooperation... I gained sociability (PT4)." It is specified that friendship relations are developed in group studies which are included in the scope of cooperative learning (Lazarowitz et al., 1994). Two of the other themes under this title are prospective teachers' views explaining that the IBT process improves their problem-solving and interpretation skills. In parallel with this finding, the other studies also state the fact that inquiry-based learning improves students' problem-solving (Büyükkaragöz \& Çivi, 1999; Açıkgöz, 2007) and interpretation skills (Soylu, 2004; Wyatt, 2005). Another theme includes the prospective teachers' views that this process improves leadership characteristics and self-confidence. Similar results to this finding are asserted in the studies of Fansa (2012), Tatar and Kuru (2006). In another theme under this title, prospective teachers expressed that students interested in different and extraordinary practices will not be concerned about inquiry-based learning. In this context, it is pointed out that the inquiry-based learning process should start with interesting questions (Sakar, 2010) and that it is also important that the inquiry-based learning environment should be designed in an interesting manner (Keller, 2001). Another theme is that the IBT process improves individual and collective decision-making skills. In this context, a prospective teacher explained her/his opinion as "...There were discussions while studying in groups; many different ideas came out and we made decision on them. Everyone gave up their decisions one by one and made a joint decision ... (PT12)."

There are three themes under the title of the benefits of IBT for preparing for the profession. According to this, prospective teachers reported that the lecturing ME course with inquiry-based teaching activities provided them with the opportunity to get to know the school environment, gain professional experience before the service and motivate them for the profession. Çalışkan (2008) states that the educational activities that students experience during the IBT process are a good experience for them. Şensoy (2009) emphasizes that IBT is effective in 


\section{Acta Educationis Generalis \\ Volume 10, 2020, Issue 3}

creating and increasing professional motivation for the prospective teachers. In the activities carried out within the scope of this study, prospective teachers participated in lessons from time to time in schools and stated that they realized students' misconceptions during this process. It is stated that inquiry-based learning activities are effective in reducing misconceptions (Kula, 2009).

There are seven themes under the title of characteristics of IBT process regarding individuals. The first is that the student has the responsibility of learning during the IBT process. These views of prospective teachers are consistent with the characteristics expressed in various studies (Açıkgöz, 2007; Akpullukçu, 2011; Massa, 2008; Tatar \& Kuru, 2006) as "In the IBT process, students undertake the responsibility of learning; they create their own learning and the aim of it is to raise the students as individuals who can learn independently."

Another theme is the views expressed by the prospective teachers that they are active in this process. The views of prospective teachers are required as it is the nature of this method and in the studies conducted by Manlove et al. (2006) and Tatar and Kuru (2006), they also mention the necessity of the students' active participation in this process. Another theme that arises from the views of prospective teachers is to access information from different sources in this process. In various studies (Açıkgöz, 2007; Çalışkan, 2008; Sungur \& Tekkaya, 2006; Wyatt, 2005; Yore, 1984), it is pointed out that the IBT process and its activities require the search of information from different sources. In another theme, prospective teachers state that the IBT process includes extracurricular activities. Inquiry-based learning should not be limited to school and class hours. Educational situations can be organized to include real-life environments and learning can take place outside the classroom (Alp et al., 2006; Knapp \& Barrie, 2001). It is even reported that students can learn better through extracurricular activities (Klemmer, Waliczek, \& Zalicek, 2005). Another theme under this title is the prospective teachers' views that time should be used well in the IBT process. IBT is time consuming and therefore, the students should be given sufficient time (Carin \& Bass, 2001). It can be said that the IBT process provides students to improve their skills in planning and using time effectively. In another theme, prospective teachers reported that they made mistakes until they reached the right information in the process. According to Üstündağ (2005), making mistakes and overcoming this mistake is an important skill. Karasar (2005) emphasizes that an individual's current misinformation leads her/him to do research. In the inquiry-based learning process, when students make mistakes, teachers should direct the students to the research rather than giving the correct information directly, so that they can access the correct information on their own (Carin \& Bass, 2001). The last theme listed under this title is that prospective teachers engage in an intensive process of asking questions in IBT. It is a characteristic feature of this approach and the inquiry-based teaching process 


\section{Acta Educationis Generalis \\ Volume 10, 2020, Issue 3}

often introduces with an interesting question or questions (Koç, 2006; Wyatt, 2005).

There are six themes under the title of characteristics related to the nature of the inquiry-based learning process. The first of these is the prospective teachers' thoughts about learning by doing-experiencing in the process. In this process, the subjects of the measurement and evaluation course are organized in a way that will enable prospective teachers to learn by doing and experiencing. Students learned how to develop tests, prepare questions, and apply alternative measurement and evaluation instruments. In the control group, these subjects were taught theoretically and with the method of direct instruction. This is understood from the statement ("First we learned by doing; Bloom's taxonomy, concept map, grid are really applied in practice ... (PT1)") of one of the prospective teachers. Another theme under this title is that prospective teachers encounter unexpected challenges in this process. According to Frankel and Wallen (2006), it is very natural for the researcher to encounter challenges in the research process. One of the themes listed under this title covers the prospective teachers' comparison of traditional teaching with IBT and their views stating that the traditional method is easier. In another doctorate study, it is mentioned that students perceive traditional teaching as easier than IBT (Parim, 2009). In another study, Benson (1998) studied IBT with the group of prospective teachers and emphasized that during the process, prospective teachers had difficulty in the process because they were accustomed to the traditional method but they got used to the method over time. Another theme under this heading is the participants' views that this method is not applicable for all courses. The prospective teachers stated that inquiry-based learning was appropriate for educational science courses and especially for the ME course, but they did not consider it as appropriate for their teaching areas, mathematics. At this point, almost the majority of prospective teachers stated that mathematics courses couldn't be taught with this method. They pointed out that mathematics is an abstract field and so the courses in this field should be lectured directly to them. It is stated that the learning outcomes of each course cannot be attained with the understanding of constructivism that this approach is not appropriate for the courses in which basic information is given, but that this approach may be appropriate for the courses in which high-level thinking and concepts are aimed to be learned in depth (Hoagland, 2000). Again under this topic, the prospective teachers asserted that teaching the measurement and evaluation course by inquiry oriented teaching activities was not directed towards KPSS and that KPSS was predominantly based on questions containing rote information, so they had to memorize the subjects down to the last detail, that KPSS posed an obstacle for them, that they had to pass this test in order to become teachers whether they want or not. Similar results are expressed in different studies (Sezgin \& Duran, 2011; Şahin-Taşkın \& Hacıömeroğlu, 2010). Sezgin and Duran (2011) state that prospective teachers' approaches of focusing on what to 


\section{Acta Educationis Generalis \\ Volume 10, 2020, Issue 3}

be asked in KPSS rather than their professional contributions to the courses in the undergraduate curriculum are grave. KPSS is a test in Turkey for prospective teachers where they should get enough points to be appointed as teachers after graduation. The participants of this study are 3rd grade prospective teachers and they will take the KPSS exam after graduation. It is understood that KPSS affects them and their motivation. Similar results are available in many studies related to the KPSS exam in the relevant literature (Akkuş, 2014; Baştürk, 2007).

There are two themes under the title of IBT process for the instructor. The first is the prospective teachers' views that they expect more feedback from the instructor. In the IBT process carried out within the scope of this study, students were given timely, in-class and out-of-class feedback about each activity, but this may not have been sufficient for some students. In the inquiry-based science course conducted with prospective teachers, it is stated that the students are in constant need of approval about the task performed, and they continuously asked questions to the instructor about whether they perform the tasks correctly or not (Kazempour \& Amirshokoohi, 2013). The reasons for the ineffectiveness of IBT are stated that in cases where the students who are accustomed to the traditional method are too much set free, inadequate guidance and inadequate feedback (Parim, 2009). The source of these ideas of teacher trainees may be related to situations, such as their not being used to this method, or that they are not independent, self-learning individuals. Another theme under this topic is towards allowing sufficient time for research and activities. They stated that the time was sufficient in the interviews, because they did not perform their duties and responsibilities in a timely manner, they had problems from time to time due to their own mistakes, they liked the flexible time periods, they reported this situation to the instructor easily when they had time problems and they received positive feedbacks. A prospective teacher said "I think the time given was enough, but we are all students (laughs). As you know, we postpone our responsibilities to the last minute; that's why it was a little bit challenging for us... Even if you give us 2 months, we will try to finish it in the last 3-5 days, so I think there are problems caused by us. In other words, the time was sufficient [PT 1]." Another student expressed her/his opinion, as "Time and duration were enough. I like the flexible working hours. The group members were already my friends and we didn't have a problem [PT]." Some prospective teachers may think that the time given is not sufficient due to their studying habits.

Five themes have emerged under the topic of factors affecting inquiry-based learning. The first is that good communication and coordination among group members is necessary in group work during IBT. In addition, prospective teachers stated that this situation affects the efficiency of the studies. Cooperation occurs in the IBT process (Hammerman, 2006). Another theme under this title is that negative attitudes and prejudice towards research affect the process. It is stated that students may have resistance to the research and 


\section{Acta Educationis Generalis \\ Volume 10, 2020, Issue 3}

therefore, students should be familiarized with this method starting from elementary school (Çalıskan, 2008). It is understandable that some of the students who experienced the IBT process may have different attitudes regarding the activities related to research and completing the process. A student's statement is meaningful in this regard: "Self-learning gives us a lot but it is also very difficult. We did not do such things in primary, middle and high school; we are not used to it. You do everything yourself, constantly research, ask, examine, work with the group, tell the group what you have learned, ask questions, answer the questions that you have asked. It is permanent but challenging and time-consuming at the same time. Sometimes you get nervous asking 'why do I have to do this?' The other group (control) doesn't do anything, they just listen and go. Our friends are traveling and having fun, while we are visiting the schools, consulting with the teachers at the university, and going to the library and reading articles. But it's permanent. [PT1]." Regarding this topic, prospective teachers considered not being accustomed to this method as one of the factors negatively affecting the inquiry-based learning process. Although there are many benefits of IBT in the literature, it is determined that teachers do not use this method very often (Welch et al., 1981). Considering the constructivist primary education programs have been in practice since the 20052006 academic year in Turkey, it can be said that this situation is also valid for our country. It is inevitable that students who take courses with traditional methods since primary education and who are familiar with traditional methods bring some habits along with them. Changing habits is difficult (Constenson \& Lawson, 1986) and time consuming. It is possible that these habits will adversely affect the inquiry-based learning process. Again, in this topic, within the framework of another theme, prospective teachers have opinions that grade concerns may affect their attitudes towards the ME course. It is stated that examoriented learners may think that they learn less with this method (Çalışkan, 2008) and this situation may affect the attitude towards the course. One of the prospective teachers thinks that "Ultimately, we had an exam (score) concern. Our thoughts and feelings could have been more positive, if we had not had any exam (score) concerns [PT7]." Finally, under this topic, prospective teachers stated that the use of IBT activities in the ME course negatively affected their motivation for the ME course as it was not directed to KPSS and other exams in the school. These findings obtained from the analysis of the interviews with prospective teachers indicate that factors such as grades and KPSS anxiety negatively affect the attitudes of prospective teachers towards the ME course. Baştürk (2007) stated that KPSS increased the anxiety of prospective teachers in his study. In addition, Akkus (2014) revealed that prospective teachers think that teaching lessons with non-traditional methods has little contribution to KPSS. Also, the test anxiety experienced by prospective teachers may affect their tendency to perspective-taking in the future (Wolgast et al., 2020). 


\section{Acta Educationis Generalis \\ Volume 10, 2020, Issue 3}

There are six themes under the topic of negative aspects of inquiry-based learning. The first is that prospective teachers perceive inquiry-based learning as a difficult process. According to Constenson and Lawson (1986), the IBT process is not easy. In another study, regarding inquiry-oriented learning, it was established that prospective teachers think that this method can have disadvantages, such as time, physical conditions, teacher preparation, inapplicability to all subjects and crowded classes, and therefore they develop negative attitudes and understandings against the method (Bayır \& Köseoğlu, 2013). Another theme is the students' views that this method may not increase interest in the ME course. During the IBT process, students' interests may decrease from time to time (Constenson \& Lawson, 1986). It is thought that the source of these thoughts of prospective teachers could be different factors, such as difficulties experienced during the process, unexpected situations, problems in group works, increase in workloads, habits, and students' perception towards practices as time consuming and exhausting. Within the scope of another theme, prospective teachers think that IBT process is time consuming and tiring. It is stated that there may be insufficient time during IBT process (Hurd et al., 1980). A prospective teacher expressed her opinions in such a way that "Obviously I wouldn't want it for every course. Because it was a very tiring process for me. The workload has increased. If it was only one course and we did these activities, it would be okay. We would do it very comfortably, but we also have other courses. This semester many courses overlapped, so, we are very tired... [PT4]." Another prospective teacher expressed his/her thoughts related to the process: "There was pros and cons. Pros were that I was leading the group, and I think it contributed to me. It gave me self-confidence. Apart from that, I learned the methods that I would really apply in my future education life. I learned to look at things from different perspectives. The cons are that it is strenuous, our workload has increased, we had to do the tasks, assignments at home that we could not finish at school and took the lessons home. For example, we prepared an exam. We have never prepared an exam so far, and we didn't know how to do it. We searched from many sources, books, looked at reliability and validity, and it was very time consuming. Workload increased, the labor increased [PT7]."

In another theme under the last topic, prospective teachers have opinions that they are not used to this method and that the idea of being responsible for their own learning creates anxiety in the process. In this context, it was pointed out that because of the negative attitude of some students, such as anxiety and boredom, IBT process can be unnerving for them and that these students should be supported (Institute for Inquiry, 1995). In the experimental process of this study, prospective teachers were given necessary information about the method, they were directed, but it might not have been enough for some students. The fact that prospective teachers think that their workload increases in IBT method is another matter that they consider negatively. Similarly, in a qualitative study 


\section{Acta Educationis Generalis \\ Volume 10, 2020, Issue 3}

investigating the views of students and instructors about the problem-based learning process, it was reported that the social life of the students was limited due to the very intensive hours, and this situation caused the students to exhibit negative attitudes towards problem-based learning especially at the beginning of the process (Biber \& Başer, 2012). In the same study, it is stated that the exams carried out in the process create weariness and reluctance in students and this situation decreases the efficiency of the process. Dochy et al. (2003) argues that the effectiveness of problem-based learning is discussed, but when positive effects are considered, negative results tend to be ignored. The other view of the prospective teachers under the topic of the negative aspects of IBT is that it is difficult to prepare alternative measurement and evaluation tools. It is stated that in some of the different studies conducted on alternative measurement and evaluation, teachers in some and prospective teachers in other studies do not prefer to use these tools and they may have different reasons. Some of these reasons are that it is difficult and time-consuming to prepare these tools, it is costly, it increases teachers' workload and teachers do not have enough information on this issue (Akbaş \& Gençtürk, 2013; Kuran \& Kanatl1, 2009; Özenç, 2013; Sağlam-Arslan et al., 2008). Prospective teachers' opinions that it is difficult to prepare alternative measurement and evaluation tools are coherent with the studies in the literature, but the reason may not be related only to the method applied. As stated by Parim (2009), the habits of prospective teachers that they bring along from the traditional method and their resistance to change can be seen among the reasons of this situation. In addition, it may emanate from the fact that the prospective teachers themselves may not have had much experience with alternative measurement and evaluation tools. Since standard tests and exams are more widely used in the education system of Turkey.

\section{Conclusion}

In this study, the course process carried out with inquiry-based teaching practices was examined within the framework of the opinions of prospective mathematics teachers. The measurement and evaluation course, which is one of the teaching undergraduate courses, was conducted within the scope of the inquiry-based teaching process and the opinions of the participants about this process were investigated. The opinions of the participants were gathered under the headings of the benefits of inquiry-based teaching for the measurement and evaluation course, the benefits of inquiry-based teaching to gain skills, the benefits of inquiry-based teaching to getting ready for the profession and the characteristics of inquiry-based teaching process regarding individuals. Furthermore, the opinions of the participants related to the headings of the characteristics of the nature of the inquiry-based teaching process, the characteristics of the inquiry-based teaching process regarding the instructor, the factors affecting inquiry-based teaching and negative aspects of inquiry-based teaching were included. 


\section{Acta Educationis Generalis \\ Volume 10, 2020, Issue 3}

Prospective teachers stated that this process provides permanent and meaningful learning, provides the opportunity to apply the lessons learned in the real life, and develops some skills such as research, problem solving, decision making, leadership. It was stated that the activities carried out during the course give prospective teachers the opportunity to get to know the real school environment and obtain professional experience. Prospective teachers stated that they had the responsibility of learning about the inquiry-based teaching process, in this way, they were active in the process and experienced an intense questioning process. They stated that they learned by doing and experiencing in the inquiry-based teaching process and reported that traditional teaching was easier than the inquiry-based teaching process. The opinion that extra-curricular activities in the process were time consuming was shared by some participants. Preservice teachers stated that inquiry-based teaching method is not suitable for all subjects, it is not particularly suitable for mathematics, but it is very suitable for educational sciences courses, especially the measurement and evaluation course. Some participants think that the instructor should give more feedback and guidance during the inquiry-based teaching process and the time given for the activities should be sufficient. Prospective teachers stated that problems such as negative attitude and bias towards research, being not accustomed to the process, exam (score) concern, lecturing the course with this method is not appropriate to KPSS negatively affect the inquiry-based teaching process. The participants stated that the inquiry-based teaching process is challenging, time consuming, tiring, increasing the workload and occasionally causing anxiety in the process. It can be said that most of the participants have positive opinions about the inquiry-based teaching process.

We live in the information age, and therefore, it is very important for each individual to grow up as individuals who can obtain information, research, question, solve problems, think critically, creatively and productively. Teachers have a great responsibility in providing these skills and features to individuals. It is particularly important that teachers acquire these skills first. However, it is not always possible to obtain these skills and features with traditional teaching understanding. Therefore, it is necessary to use modern learning-teaching approaches in teacher education. One of them is the inquiry-based learningteaching approach. In this study, prospective teachers stated that the course taught with this method contributed significantly to the process. There is another important benefit of using contemporary learning approaches in teacher education. In the renewed primary, secondary and high school curriculum, traditional teaching understanding has been eliminated in Turkey and studentcentered, different contemporary teaching and learning methods have been adopted. On the other hand, it can be said that teacher education is mostly carried out with traditional understanding and methods. It will be very beneficial for prospective teachers to experience the approaches and methods that they will apply in their professional lives before starting the profession. In this context, it 


\section{Acta Educationis Generalis \\ Volume 10, 2020, Issue 3}

can be suggested to use both the inquiry-based learning-teaching approach that is the subject of this study and other learner-centered approaches in teacher education. Furthermore, the applicability of inquiry-based teaching in other educational sciences courses other than the measurement and evaluation course can be researched. In order to develop students' research awareness and competencies and to decrease their research anxiety, this method can be applied from primary school level and students can get used to inquiry-based learning method. It should be taken into consideration that deep-rooted beliefs and habits of students obtained from previous educational experiences make it difficult to apply this model. Studies evaluating the effect of this method at undergraduate or graduate levels, especially in abstract fields such as mathematics and in different courses can be conducted.

\section{References}

Açıkgöz, K. Ü. (2007). Aktif ögrrenme (9th ed.). İzmir: Biliş Publications.

Akbaş, Y., \& Gençtürk, E. (2013). Geography teachers' views about alternative assessment and evaluation techniques: Usage levels problems and limitations. Atatürk University Eastern Geographical Review, 18(30), 331356.

Akınoğlu, O. (2004). Yapılandırmacı öğrenme ve coğrafya öğretimi. International Journal of Geography and Geography Education, 10, 73-94.

Akkuş, Z. (2014). Views of pre-service teachers of social studies about the assessment and evaluation activities based on constructive approach. Selçuk University Journal of Institute of Social Sciences, 31, 13-27.

Akpullukçu, S. (2011). The Effect of Inquiry-Based Learning Environment in Science and Technology Course on the Students' Academic Achievements, Attitudes and Retention Level (unpublished Master thesis). İzmir, Turkey: Dokuz Eylül University.

Alkan-Dilbaz, G., Yanpar-Yelken, T., \& Özgelen, S. (2013). The effects of research-based learning on primary school students. Firat University Journal of Social Science, 23(1), 89-103.

Alp, E., Ertepınar, H., Tekkaya, C., \& Yılmaz, A. (2006). İlköğretim öğrencilerinin çevreye yönelik tutum ve bilgileri üzerine bir çalışma. In The 7th National Science and Mathematics Education Congress Abstracts Book. Ankara: Palme Publications.

Baştürk, R. (2007). Investigation of test anxiety levels of pre-service teachers taking civil servant selection examination. Firat University Journal of Social Science, 17(2), 163-176.

Bayır, E., \& Köseoğlu, F. (2013). Getting pre-service chemistry teachers to construct understanding about inquiry-based teaching. Asya Journal of Instruction, 1(2), 29-43. 


\section{Acta Educationis Generalis \\ Volume 10, 2020, Issue 3}

Benson, J. (1998). Using an inquiry approach with preservice teachers to explain the process of facts, concept, and generalization. The Social Studies, 89(5), 227-231.

Biber, M., \& Başer, N. (2012). Probleme dayalı öğrenme sürecine yönelik nitel bir değerlendirme. HAYEF: Journal of Education, 17, 12-33.

Bostan-Sarığlan, A., Can, Y., \& Gedik, İ. (2016). The assessment of the suitability of the activities in 6th grade science course books for inquiry based learning approach. Abant İzet Baysal University Journal of Faculty of Education, 16(3), 1004-1025.

Büyükkaragöz, S., \& Çivi, C. (1999). Genel öğretim metotları öğretimde planlama uygulama (10th ed.). İstanbul: Beta Publications.

Carin, A. A., \& Bass, J. E. (2001). Teaching Science as Inquiry. New Jersey: Prentice-Hall, Inc., Upper Saddle River.

Chang, C., Chang, C.-K., \& Shih, J.-L. (2016). Motivational strategies in a mobile inquiry-based language learning setting. System, 59, 100-115.

Constenson, K., \& Lawson, A. (1986). Why isn't inquiry used in more classrooms? The American Biology Teacher, 48(3), 150-158.

Creswell, J. W. (2013). Research Design Qualitative, Quantitative, and Mixed Methods Approaches (4th ed.). California: Sage Publications, Inc.

Çalışkan, H. (2008). The Effect of Inquiry-Based Learning Approaches in 7th Grade Social Studies Course in Primary School on Attitude Towards Course, Academic Achievement and the Degrees of Retention (unpublished Doctoral thesis). Ankara, Turkey: Gazi University.

Çalışkan, H., \& Turan, R. (2008). The effect of inquiry-based learning approaches in social studies course on academic achievement and the degrees of retention. The Journal of Turkish Educational Sciences, 6(4), 603-627.

Dochy, F., Segers, M., Van den Bossche, P., \& Gijbels, D. (2003). Effects of problem-based learning: A meta-analysis. Learning and Instruction, 13(5), 533-568.

Duran, M., \& Dökme, İ. (2018). The Effect of inquiry-based learning approach on conceptual understanding level and some learning outcomes. Trakya Journal of Education, 8(3), 545-563.

Ekiz, D. (2009). Bilimsel Araştırma Yöntemleri (2nd ed.). Ankara: Anı Publications.

Fansa, M. (2012). The Effect of Inquiry-Based Learning Approaches in the Education of Science in Primary School on the Science Process Skills, Academic Achievement and Attitude (unpublished Master thesis). Hatay, Turkey: Mustafa Kemal University.

Fraenkel, J. R., \& Wallen, N. E. (2006). How to Design and Evaluate Research in Education (6th Ed.). New York: Mac Graw Hill, Inc.

Hammer, D. (1997). Discovery learning and discovery teaching. Cognition and Instruction, 15(4), 485-529. 


\section{Acta Educationis Generalis \\ Volume 10, 2020, Issue 3}

Hammerman, E. (2006). 8 Essentials of Inquiry-Based Science, K-8. California: Corwin Press.

Heindl, M. (2019). Inquiry-based learning and the pre-requisite for its use in science at school: A meta-analysis. Journal of Pedagogical Research, 3(2), 52-61.

Hoagland, M. A. (2000). Utilizing Constructivism in the History Classroom. Retrieved from http://files.eric.ed.gov/fulltext/ED482436.psd

Hurd, P. D., Bybee, R. W., Kahle, J. B., \& Yager, R. E. (1980). Biology education in secondary schools of the United States. The American Biology Teacher, 42(7), 388-404.

Hwang, G.-J., Chiu, L.-Y., \& Chen, C.-H. (2015). A contextual game-based learning approach to improving students' inquiry-based learning performance in social studies courses. Computers \& Education, 81, 13-25.

Institute for Inquiry. (1995). Inquiry Based Science: What Does It Look Like? Retrieved from http://www.exploratorium.edu/IFI/resources/classroom/ inquiry_based.html

Karasar, N. (2005). Bilimsel araştırma yöntemleri. Ankara: Nobel Publications.

Kazempour, M., \& Amirshokoohi, A. (2013). Exploring elementary pre-service teachers' experiences and learning outcomes in a revised inquiry-based science lesson: an action research. Journal of Education and Learning, 2(2), 144-154.

Keller, T. J. (2001). From Theory to Practice Creating an Inquiry-Based Science Classroom (unpublished Master thesis). Lutheran University.

Klemmer, C. D., Waliczek, T. M. \& Zajicek, J. M. (2005). Growing minds: The effect of a school gardening program on the science achievement of elementary students. HortTechnology, 15(3), 448-452.

Koç, G. (2006). Teacher-learner roles and interaction systems in constructivist classrooms. Education and Science, 31(142), 56-64.

Knapp, D., \& Barrie, E. (2001). Content evaluation of an environmental science field trip. Journal of Science Education and Technology, 10(4), 351-357.

Kula, Ş. G. (2009). The Effect of Inquiry-Based Science Learning on the Students' Science Process Skills, Achievement, Concept Learning and Attitude (unpublished Master thesis). İstanbul, Turkey: Marmara University.

Kuran, K., \& Kanatl1, F. (2009). The evaluation of classroom teachers' opinions on the alternative assessments techniques. Mustafa Kemal University Journal of Social Sciences Institute, 6(12), 209-234.

Lazarowitz, R., Hertz-Lazarowitz, R., \& Baird, H. (1994). Learning science in a cooperative setting: academic achievement and affective outcomes. Journal of Research in Science Teaching, 31(10), 1121-1131.

Leonhardt, A. N. (1998). An ecological system curriculum: an integrated MST approach to environmental science education. The Annual Meeting of the 


\section{Acta Educationis Generalis \\ Volume 10, 2020, Issue 3}

International Consortium for Research in Science and Mathematics Education. Trinidad: Port of Spain.

Madill, H. M., Amort-Larson, G., Wilson, S. A., Brintnell, S. G., Taylor, E., \& Esmail, S. (2001). Inquiry-based learning: An instructional alternative for occupational therapy education. Occupational Therapy International, 8(3), 198-209.

Manlove, S., Lazonder, A. W., \& De Jong, T. (2006). Regulative support for collaborative scientific inquiry learning. Journal of Computer Assisted Learning, 22, 87-98.

Massa, N. M. (2008). Problem-based learning (PBL): A real-world antidote to the standards and testing regime. New England Journal of Higher Education, 22(4), 19-20.

MNE. (2018). Science Course Curriculum (Primary and secondary school 3, 4, 5, 6, 7 and 8. classes). Retrieved from http://mufredat.meb.gov.tr/ProgramDetay.aspx?PID=325

Miles, M. B., \& Huberman, A. M. (1994). Qualitative data analysis: An expanded sourcebook (2nd ed.). Thousand Oaks, CA: Sage.

Özenç, M. (2013). Determination of levels of primary school teachers' alternative assessment and evaluation knowledge. Dicle University Ziya Gökalp Journal of Education, 21, 157-178.

Parim, G. (2009). The Effects of Inquiry on the Concept Learning, Achievement and Development of Scientific Process Skills of 8th Grade Students as Related to Photosynthesis and Respiration (unpublished Doctoral thesis). İstanbul, Turkey: Marmara University.

Saban, A. (2009). Content analysis of Turkish studies about the multiple intelligences theory. Educational Sciences: Theory \& Practice, 9(2), 833876.

Sağlam-Arslan, A., Avc1, N., \& İyibil, G. (2008). Physics prospective teachers' perception levels concerning alternative evaluations methods. Dicle University Ziya Gökalp Journal of Education, 11, 115-128.

Sakar, Ç. (2010). The Effect of Inquiry Based Chemistry Teaching on Student's Academic Achievement and Attitude (unpublished Master thesis). Konya, Turkey: Selçuk University.

Sezgin, F., \& Duran, E. (2011). The reflections of the public personnel selection examination on teacher candidates' academic and social lives. Turkish Journal of Social Research, 153, 9-22.

Soylu, H. (2004). Fen Öğretiminde yeni yaklaşımlar: Keşif yoluyla öğrenme. Ankara: Nobel Publications.

Stacey, G., Wilson, C., Reddy, H., Palmer, C., Henderson, J., Little, H., \& Bull, H. (2018). Diagnosing and treating enquiry based learning fatigue in graduate entry nursing students. Nurse Education in Practice, 28, 310-313. 


\section{Acta Educationis Generalis \\ Volume 10, 2020, Issue 3}

Sungur, S., \& Tekkaya, C. (2006). Effects of problem-based learning and traditional instruction on self-regulated learning. The Journal of Educational Research, 99(5), 307-320.

Şahin-Taşkın, Ç., \& Hacıömeroğlu, G. (2010). Importance of pedagogy courses on preservice teachers' professional development. Pamukkale University Journal of Education, 28, 165-174.

Şensoy, Ö. (2009). The Effect of Inquiry-Based Science Instruction According to the Constructivist Approach on Preservice Teachers' Problem Solving Skills, Self-Efficacy and Achievements (unpublished Doctoral thesis). Ankara, Turkey: Gazi University.

Tatar, N., \& Kuru, M. (2006). The effect of inquiry-based learning approach in science education on academic achievement. Hacettepe University Journal of Education, 31, 147-158.

Üstündağ, T. (2005). Journey to the Creativeness. Ankara: PegemA Publications.

Vilardi, V. A. (2013). An Examination of the Influence of Inquiry-Based Laboratory Activities and Success on Standards Based Achievement Tests in a Suburban High School (unpublished Doctoral thesis). Alabama: Alabama University.

Welch, W. W., Klopfer, L. E., Aikenhead, G. S., \& Robinson, J. T. (1981). The role of inquiry in science education: Analysis and recommendations. Science Education, 65(1), 33-50.

Wolgast, A., Hille, M., Streit, P., \& Grützemann, W. (2020). Does test-anxiety experience impair student teachers' later tendency to perspective-taking? Acta Educationis Generalis, 10(1), 1-24. https://doi.org/10.2478/atd-20200001

Wyatt, S. (2005). Extending inquiry-based learning to include original experimentation. The Journal of General Education, 54(2) 83-89.

Yore, L. D. (1984). The effects of cognitive development and age on elementary students' science achievement for structured inductive and semi-deductive inquiry strategies. Journal of Research in Science Teaching, 21(7), 745753. 